Aim of the study: Despite significant progress in the pathology of clear cell renal cell carcinoma (cCRCC), diagnostic and predictive factors of major importance have not been discovered. Some hopes are associated with insulin-like growth factors. The aim of the study was to compare the expression of genes for insulin-like growth factor family in tumours and in tissue of kidneys without cancer.

Material and methods: Fifty-two patients years with clear cell renal cell cancer were qualified to the study group; patients nephrectomised because of hydronephrosis were included in the control group. Expression of genes were evaluated by RT-PCR. Results: Expression of IGFR-1 gene in tumour accounts for about $60 \%$ of cases. The incidence is higher than in corresponding adjacent non-cancerous kidney tissues and higher (but with no statistical significance) than in kidney without cancer.

Expression of IGFR-2 gene in tumours has not been established. The incidence of the expression in corresponding adjacent non-cancerous kidney tissues is small. Expression of this gene has been present in all specimens from kidneys without cancer. Expression of IGFBP-3 gene ascertained in all (except four) cases of cCRCC and in the majority of clippings from adjacent tissue. It was not found in kidneys from the control group. IGF-1, IGF-2, and IGFR-1 mRNA copy numbers in $\mathrm{cCRCC}$ were higher than in the material from the control group

Key words: insulin-like growth factors, clear cell renal cell carcinoma, RT-PCR.

Contemp Oncol (Pozn) 2016; 20 (2): 130-136 DOI: $10.5114 /$ wo.2016.58720

\section{Expression of insulin-like growth factor family genes in clear cell renal cell carcinoma}

\author{
Ryszard Braczkowski ${ }^{1}$, Michał Białożyt ${ }^{2}$, Marta Plato ${ }^{3}$, Urszula Mazurek \\ Bogumiła Braczkowska ${ }^{5}$
}

${ }^{1}$ Department of Public Health, School of Public Health, Silesian Medical University, Katowice, Poland

${ }^{2}$ Prof. Michałowski Memory Hospital, Katowice, Poland

${ }^{3}$ Department of Pharmaclogy, School of Medicine, Silesian Medical University, Katowice, Poland

${ }^{4}$ Department of Molecular Biology, School of Pharmacology, Silesian Medical University, Katowice, Poland

5epartment of Epidemiology, School of Medicine Katowice, Silesian Medical University, Katowice, Poland

\section{Introduction}

The incidence of renal cancer is increasing annually by about $2 \%$ [1]. According to recent data it represents $2-3 \%$ of all human malignant neoplasms [2]. In Poland, as well as in the Czech Republic, it is burdened with a high mortality level, and therefore it is considered one of the most important urological cancers in Central and Eastern Europe [3]. Renal cell carcinoma (RCC) is the most common type of kidney cancer in adults. Clear cell renal cell carcinoma (cCRCC) is a distinct subtype of RCC, and the most frequent. Kidney cancer develops as a result of abnormalities in the genetic material, which occur as a result of inheritance as well as changes acquired as a result of environmental impact [4]. Tumour stage and grade are considered as the only widely accepted prognostic markers of RCC.

Insulin-like growth factors 1 and 2 (IGFs) are peptides with promitotic and antiapoptotic effects. The action of both IGFs goes through the activation of receptor IGF type 1 (IGFR-1), a transmembrane receptor with tyrosine kinase activity, and in a small part through the activation of insulin receptor [5]. Another type of receptor, IGF receptor type 2 (IGFR-2), has no tyrosine-kinase activity and does not exert mitogenic and antiapoptotic action. This receptor is identical to the mannose-6-phosphate receptor (IGF-II/M6P-R). Activity of IGFs is regulated by their binding proteins (IGFBPs), most important of which is IGFBP-3. Activation of IGFR-1 promotes growth of many cancers [6-8]. Elevated level of IGF-1 and reduced IGFBP-3 in blood can be associated with an increased risk of cancer [9]. Increased incidence of colorectal cancer has been seen in acromegaly, in which hypersecretion of growth hormone $(\mathrm{GH})$ is followed by elevated IGF-I levels [10]. The GH/IGF system is implicated in growth regulation of the kidney during embryogenesis. Treatment with $\mathrm{GH}$ and IGF increases kidney size and glomerular filtration rate [11, 12]. IGFs are also involved in pathological process, such as nephritis and glomerulosclerosis [13]. Against this background we may suspect that IGFs can promote the development and growth of cCRCC.

The aim of the study was to demonstrate the expression of genes for IGFs, IGFBP-3, and IGF receptors in cCRCC.

\section{Material and methods}

Patients qualified to radical nephrectomy were included to the study. The exclusion criteria were as follows: diagnosed diabetes mellitus, previously 
treated cancer, any form of hormonal therapy. Sixty-two patients suffering from kidney cancer were included into the examined group and 30 patients (age 32-63) nephrectomised because of hydronephrosis were included into the control group (the number of patients is smaller than in the tested group, but it results in a small number of nephrectomies made for reasons other than cancer). Permission for the study was obtained from the Ethics Committee of Silesian Medical University (NN 6501-2004/06/07), and each patient gave written informed consent. Patients were operated and tissues were collected for histopathology. Cancer tissues and tissues from the pole of the kidney opposite to the tumour were collected for RNA extraction and immediately stored in the tank with liquid nitrogen. Only materials obtained from patients with tumours qualified as cCRCC were included to further study. Finally, 52 patients aged 35-65 years were qualified into the examined group. The clinical-pathological characteristics of this group are presented in Table 1. For all patients, nuclear grading was determined by the criteria proposed by Fuhrman et al. [14].

\section{RNA extraction from tissue specimens}

Total RNA was extracted from cells using an RNeasy mini purification kit (Qiagen, Valencia, CA) according to the manufacturer's protocol.

\section{Quantitative RT-PCR assay}

Expressions of genes were evaluated using real-time RT-PCR and SYBR Green I chemistry (SYBR Green Quantitect RT-PCR Kit; QIAGEN, Valencia, CA). The analysis was performed using an Opticon ${ }^{\mathrm{TM}}$ DNA Engine Continuous Fluorescence Detector (MJ Research, Watertown, MA). GAPDH gene was included to monitor the RT-PCR efficiency as an endogenous positive control of amplification and integrity of extracts.

Oligonucleotide primers (Table 2) were designed in the Department of Molecular Biology of Silesian Medical University on the basis of reference sequences (http:// www.ncbi.nlm.nih.gov). Detection of GAPDH gene was performed according Ercolani et al. [15], and $\beta$-actin was detected according to Nakajima-lijima et al. [16].
Table 1. Characteristics of the study group

\begin{tabular}{lcc}
\hline Characteristics & Number & Age (years) \\
All group & 52 & $41-65$ \\
Male & 25 & $41-65$ \\
Female & 27 & $41-65$ \\
Tumour size $(\mathrm{cm}) \leq 7$ & 34 & \\
Tumour size $(\mathrm{cm})>7$ & 18 & \\
TNM & & \\
T1a & 13 & \\
T1b & 21 & \\
T2a & 6 & \\
T2b & 1 & \\
T3a & 7 & \\
T3b & 2 & \\
T4 & 2 & \\
Regional lymph nodes & \\
N0 & 41 & \\
N1 & 11 & \\
N2 & 0 & \\
Distant metastases & \\
M0 & 52 \\
M1 &
\end{tabular}

To quantify the results obtained a standard curve method was employed. Commercially available standards of $\beta$-actin (ACTB) CDNA (TaqMan ${ }^{\circledR}$ DNA Template Reagent Kit; PE Applied Biosystems, Inc., Foster, CA) were used at five different concentrations to simultaneously detect the expression profile of each gene. The obtained results of mRNA copy number were recalculated per $\mu g$ of total RNA.

\section{Statistical methods}

Statistical analyses were performed using Statistica 9.0 software (StatSoft, Tulsa, OK). Values were expressed as mean and standard error, as well as median and dispersion for tested parameters. Non-parametric Mann-Whitney $U$ test was used for analyses. The prevalence of expression of tested parameters was calculated, and the results were compared using $\chi^{2}$ test, and $\chi^{2}$ with Yates' correction, depending on the calculation of the expected value. Cra-

Table 2. The sequence of primers used for RT-PCR

\begin{tabular}{|c|c|c|c|c|}
\hline Gene & $\begin{array}{l}\text { Sequence of } \\
\text { primers }\end{array}$ & Oligonucleotide sequence & $\begin{array}{l}\text { Localization } \\
\text { mRNA }\end{array}$ & Amplimer \\
\hline \multirow{2}{*}{$\begin{array}{l}\text { Homo sapiens insulin-like growth } \\
\text { factor-1 (IGF-1) }\end{array}$} & IGF-1 F & 5’ TGCTTCCGGAGCTGTGATC 3' & $452-470$ & \multirow[t]{2}{*}{$221 \mathrm{bp}$} \\
\hline & IGF-1 R & 5’ GATCCTGCGGTGGCATGTCACTCTTCACT 3' & $645-673$ & \\
\hline \multirow{2}{*}{$\begin{array}{l}\text { Homo sapiens insulin-like growth factor } \\
\text { receptor-1 (IGFR-1) }\end{array}$} & IGFR-1 F & 5' ACGCCAATAAGTTCGTCCACAGAGACCT 3' & $3425-3452$ & \multirow[t]{2}{*}{187 bp } \\
\hline & IGFR-1 R & 5’ GAAGACTCCATCCTTGAGGGACTCAG 3' & $3587-3612$ & \\
\hline \multirow{2}{*}{$\begin{array}{l}\text { Homo sapiens insulin-like growth } \\
\text { factor-2 (IGF-2) }\end{array}$} & IGF-2 F & 5' CGTTGAGGAGTGCTGTTTCC 3' & $750-769$ & \multirow[t]{2}{*}{129 bp } \\
\hline & IGF-2 R & 5' GGGGTATCTGGGGAAGTTGT 3' & $860-879$ & \\
\hline \multirow{2}{*}{$\begin{array}{l}\text { Homo sapiens insulin-like growth factor } \\
\text { receptor-2 (IGFR-2) }\end{array}$} & IGFR-2 F & 5’ TGGCAGGTCTCCTGACTCAGAAGCTAAC 3' & $4028-4055$ & \multirow[t]{2}{*}{121 bp } \\
\hline & IGFR-2 R & 5' GTCACAGTAGAAGAAGATGGCTGTGGAGC 3' & 4121-4149 & \\
\hline \multirow{2}{*}{$\begin{array}{l}\text { Insulin-like growth factor binding } \\
\text { protein-3 (IGFBP -3), transcript variant } 2\end{array}$} & IGFBP-3 F & 5' GCTACAGCATGCAGAGCAAGT 3' & $986-1006$ & \multirow[t]{2}{*}{102 bp } \\
\hline & IGFBP-3 R & 5' CAGCTGCTGGTCATGTCCTT 3’' & $1069-1088$ & \\
\hline
\end{tabular}


Table 3. Presence of expression of genes for IGF-1, IGF-2, their receptors, and IGFBP-3 in ccRCC and their corresponding adjacent non-cancerous kidney tissues (NKT)

\begin{tabular}{|c|c|c|c|c|c|c|}
\hline Group/gene & & IGF-I & IGF-2 & IGFR-1 & IGFR-2 & IGFBP-3 \\
\hline \multirow[t]{2}{*}{$\begin{array}{l}\text { CCRCC } \\
(n=52)\end{array}$} & $\begin{array}{l}\text { number with presence } \\
\text { of expression }\end{array}$ & 11 & 13 & 32 & 3 & 48 \\
\hline & $\%$ & 21.2 & 25 & 61.1 & 5.7 & 92.3 \\
\hline \multirow[t]{2}{*}{$\begin{array}{l}\text { NKT } \\
(n=52)\end{array}$} & $\begin{array}{l}\text { number with presence } \\
\text { of expression }\end{array}$ & 5 & 15 & 11 & 11 & 42 \\
\hline & $\%$ & 9.4 & 29.9 & 21.1 & 21.1 & 80.9 \\
\hline $\begin{array}{l}\text { Differences between } \\
\text { groups }\left(\chi^{2}\right)\end{array}$ & & $p=0.1323$ & $p=0.6307$ & $p<0.05$ & $p<0.05$ & $p=0.1309$ \\
\hline
\end{tabular}

Table 4. Number of mRNA copies per $\mu$ g of total RNA of IGF-1, IGF-2, receptors, and IGFBP-3 in cCRCC and their corresponding adjacent non-cancerous kidney tissues (NKT). Full analysis for IGFR-2 gene was not applied because of the small number of slices from ccRCC in which expression was observed

\begin{tabular}{|c|c|c|c|c|c|c|}
\hline Group/gene & & IGF-I & $I G F-2$ & IGFR-1 & IGFR-2 & IGFBP-3 \\
\hline $\begin{array}{l}\text { ccRCC } \\
(n=52)\end{array}$ & $\begin{array}{l}\text { number with presence of expression } \\
\text { average } \pm \text { SEM } \\
\text { median } \\
\text { min.-max. }\end{array}$ & $\begin{array}{c}11 \\
24846 \pm 5986 \\
30671 \\
6112-49640\end{array}$ & $\begin{array}{c}13 \\
146717 \pm 15928 \\
153206 \\
64872-243151\end{array}$ & $\begin{array}{c}32 \\
33835 \pm 4562 \\
25819 \\
4507-84890\end{array}$ & $\begin{array}{c}3 \\
5.7 \\
* 8504 ; 14926 \\
20773\end{array}$ & $\begin{array}{c}48 \\
6213 \pm 813 \\
4688 \\
378-21022\end{array}$ \\
\hline $\begin{array}{l}\text { NKT } \\
(n=52)\end{array}$ & $\begin{array}{l}\text { number with presence of expression } \\
\text { average } \pm \text { SEM } \\
\text { median } \\
\text { min.-max. }\end{array}$ & $\begin{array}{c}5 \\
7351 \pm 3851 \\
5870 \\
3082-27298\end{array}$ & $\begin{array}{c}15 \\
165416 \pm 23290 \\
127212 \\
73487-345742\end{array}$ & $\begin{array}{c}11 \\
15721 \pm 2131 \\
113123 \\
10358-31404\end{array}$ & $\begin{array}{c}11 \\
7377 \pm 1710 \\
404848 \\
147178-753475\end{array}$ & $\begin{array}{c}42 \\
7651 \pm 1267 \\
5682 \\
1153-27198\end{array}$ \\
\hline $\begin{array}{l}\text { Mann- } \\
\text { Whitney } \\
\text { U-test }\end{array}$ & & $p=0.05$ & $p=0.7943$ & $p<0.05$ & & $p=0.4007$ \\
\hline
\end{tabular}

Table 5. Presence of expression of genes for IGF-1, IGF-2, their receptors, and IGFBP-3 in ccRCC and kidneys with hydronephrosis (control)

\begin{tabular}{|c|c|c|c|c|c|c|}
\hline Group/gene & & IGF-1 & IGF-2 & IGFR-1 & IGFR-2 & IGFBP-3 \\
\hline \multirow[t]{2}{*}{$\begin{array}{l}\text { CCRCC } \\
(n=52)\end{array}$} & $\begin{array}{l}\text { number with presence of expression } \\
\%\end{array}$ & 11 & 13 & 32 & 3 & 48 \\
\hline & & 21.2 & 25 & 61.1 & 5.7 & 92.3 \\
\hline \multirow[t]{2}{*}{$\begin{array}{l}\text { Control } \\
(n=30)\end{array}$} & $\begin{array}{l}\text { number with presence of expression } \\
\%\end{array}$ & 23 & 24 & 14 & 30 & 0 \\
\hline & & 76.7 & 85.7 & 46.7 & 100 & 0 \\
\hline $\begin{array}{l}\text { Differences between } \\
\text { groups }\left(\chi^{2}\right)\end{array}$ & & $p<0.05$ & $p<0.05$ & $p=0.2468$ & $p<0.05$ & \\
\hline
\end{tabular}

mer's $\vee$ was used to evaluate the degree of association between Fuhrman grade and IGFs family gene expression.

\section{Results}

\section{Fuhrman grade}

Distribution of Fuhrman nuclear grade was as follows: grade $1-13$, grade $2-29$, grade $3-8$, grade $4-2$.

\section{Gene expression in ccRCC tissue and non-} cancerous kidney pole tissue, and differences between groups (Table 3 )

Only in small number of both tissues was expression IGF-1 of genes observed. There was no statistically significant difference in the incidence of this expression. Expression of IGF-2 genes was observed in a small number of cas- es; the number of slices with expression was similar. The expression of IGFR-1 gene was observed in $61.1 \%$ of slices of cCRCC. Incidence in cancer was higher than in tissue free of cancer. The IGFR-2 gene expression was rarely observed in both tissues. In ccRCC it was observed only in three cases and in the free of cancer pole of kidney in 11 cases. The difference was significant. In two cases, expression occurred in both tissues (not presented). IGFBP-3 gene expression was observed in the majority of cases in both groups.

\section{Number of mRNA copies in cCRCC and non- cancerous kidney pole tissue (Table 4)}

IGF-1. Number of transcripts in CCRCC is higher than in non-cancerous kidney pole tissue. /GF-2. There is no significant difference in number mRNA copies. 
Table 6. Number of mRNA copies per $\mu$ g of total RNA of IGF-1, IGF-2, their receptors, and IGFBP-3 in ccRCC and kidney with hydronephrosis (control). Full analysis for IGFR-2 gene was not applied, because only in 3 slices from ccRCC Full analysis for IGFBP-3 gene was not applied because no expression of this gene was ascertained in the control group

\begin{tabular}{|c|c|c|c|c|c|c|}
\hline Group/gene & & $I G F-I$ & $I G F-2$ & IGFR-1 & IGFR-2 & IGFBP-3 \\
\hline $\begin{array}{l}\text { cCRCC } \\
(n=52)\end{array}$ & $\begin{array}{l}\text { number with presence of expression } \\
\text { average } \pm \text { SEM } \\
\text { median } \\
\text { min.-max. }\end{array}$ & $\begin{array}{c}11 \\
24846 \pm 5986 \\
30671 \\
6112-49640\end{array}$ & $\begin{array}{c}13 \\
146717 \pm 15928 \\
153206 \\
64872-243151\end{array}$ & $\begin{array}{c}32 \\
33835 \pm 4562 \\
25819 \\
4507-84890\end{array}$ & $\begin{array}{c}3 \\
5.7 \\
{ }^{*} 14926 ; 8504 ; \\
20773\end{array}$ & $\begin{array}{c}48 \\
6213 \pm 813 \\
4688 \\
378-21022\end{array}$ \\
\hline $\begin{array}{l}\text { Control } \\
(n=52)\end{array}$ & $\begin{array}{l}\text { number with presence of expression } \\
\text { average } \pm \text { SEM } \\
\text { median } \\
\text { min.-max. }\end{array}$ & $\begin{array}{c}23 \\
288 \pm 48 \\
240 \\
93-780\end{array}$ & $\begin{array}{c}24 \\
36560 \pm 3162 \\
39964 \\
14317-56917\end{array}$ & $\begin{array}{c}13 \\
1845 \pm 318 \\
1560 \\
696-3734\end{array}$ & $\begin{array}{c}28 \\
7377 \pm 1710 \\
2499 \\
917-24380\end{array}$ & 0 \\
\hline $\begin{array}{l}\text { Mann-Whitney } \\
\text { U-test }\end{array}$ & & $p<0.05$ & $p<0.05$ & $p<0.05$ & & \\
\hline
\end{tabular}

min-minimum; max-maximum

IGFR-1. Number of transcripts is higher in cancer.

IGFR-2. Due to the small amount of cases in CCRCC no statistical analysis was performed.

IGFBP-3. There was no difference between groups.

\section{Gene expression in ccRCC tissue and kidney with hydronephrosis (Table 5)}

IGF-1 and IGF-2. Expression in the material from kidneys with hydronephrosis was ascertained as being more likely in specimens of ccRCC.

IGFR-1. Expression was more likely ascertained in CCRCC, but without statistical significance.

IGFR-2. As presented above in cCRCC, expression was been established (except in three cases). Expression was present in all specimens from kidney without cancer.

IGFBP-3 gene. Expression ascertained in all (except four) cases of ccRCC. Expression was found in kidneys with hydronephrosis.

Number of mRNA copies and differences between cCRCC tissue and kidney with hydronephrosis (control) (presented in Table 6)

IGF-1 and IGF-2. The number in tumours is higher than in kidneys from the control group.

IGFR-1. mRNA copy number in slices from ccRCC is higher than in kidneys of the control group.

IGFR-2. As shown above, gene expression was found only in three cases of ccRCC, no further analysis was carried out.

IGFBP-3. As shown above, the expression was not found in any slice from kidney without cCRCC. No further comparison between groups was performed.

Fuhrman grade and expression of tested genes (because of the small number of cases, grade 3 and 4 were grouped together)

IGF-1 gene. There was no expression in grade 3 and 4 Expression in grade 2 was more likely ascertained (31\%) than in grade 1 . V Cramer (VC) was 0.34 , force of dependence was low.
IGF-2 gene. Expression was most frequently ascertained in grade 3 and 4 (40\%) than in grade $2(17.2 \%)$ and in grade $1(15.4 \%)$. VC -0.23 . The force of dependence was low.

IGFR-1 gene. Expression in grade 3 and 4 was observed in $70 \%$, in grade 2 - in $62 \%$, in grade $1-38.5 \%$. VC 040 . The force of dependence was moderate.

IGFR-2 gene. No expression was observed in grade 1. In slices with higher Fuhrman grade it was observed in three cases.

IGFBP-3 gene. Expression was observed in almost all cases; there was no difference between groups.

\section{Discussion}

Although renal cell carcinoma is one of the most common, so far prognostic and predictive factors of significant importance have not been found. Some hope could be associated with insulin-like growth factors. Their elevated levels in blood have been demonstrated in breast, colorectal, and prostate cancer $[17,18]$. The value of this observation in renal cancer seems to be small. Moreover, Rasmuson et al. have shown that elevated levels of IGF-1 in sera may be a favourable prognostic factor [19]. Therefore, we assumed to track the expression of IGFs and their receptors genes in tumour tissue and diseased kidney was more appropriate than levels in serum.

Because it is impossible to take material from healthy kidney, we included material from kidneys removed because of hydronephrosis to the control group.

In tissue originating from cCRCC, the presence of IGF-1 mRNA occurs less frequently than in kidney with hydronephrosis. The presence of the expression tissue of kidney in free of cancer with ccRCC is similar to its presence in cancer. There is no expression in tumours with high (3 and 4) Fuhrman grade. So we can suppose that IGF-1 production in ccRCC can be blocked. This partly explains the cited above results of Rasmuson. Although the expression of IGF-1 and IGF-2 genes in tumours is observed less frequently than in tissue of kidneys free of cancer, the number of transcripts is several or even tens of thousands of times higher.

Promitotic and antiapoptotic activity of both IGFs were revealed after joining with IGFR-1. Expression of IGFR-1 
gene in ccRCC tissue is admittedly not observed in all cases, but appears with a higher rate than in tissue from the pole of kidney free of cancer with ccRCC, and slightly more often but with no statistical significance than in kidneys with hydronephrosis. Again, when expression occurs, the number of mNA transcripts in tumour is always dozens, hundreds, or even thousands of times higher than in kidney without cancer. IGFR-1 expression has been demonstrated earlier in a few studies related to various cancers. These researches have been focused on the study of protein as well as genes. Tumours demonstrating the presence of receptor protein were often characterised by a particularly aggressive course $[20,21]$. When studies were devoted to the gene, the relationship was not so clear. The possibility that increased expression of IGFR-1 gene could be a negative prognostic factor in epithelial ovarian cancer was indicated by the results of Spentzos et al. [22], while Dziadziuszko et al. showed the opposite situation [23]. In his study a high IGFR-1 gene copy number in tumour was associated with better survival of patients with operable non-small cell lung cancer. Increased expression of IGFR-1 in CCRCC was demonstrated Parker et al. and Sichani et al. They highlighted that high expression of IGFR-1 may be a negative prognostic factor [24, 25]. Increased expression of IGFR-1 gene in CCRCC was shown by Yuen et al., pointing out the possibility of blocking this receptor in patients with advanced cancer $[26,27]$. Results of our study show that this expression is moderately rising with Fuhrman grade.

Expression of IGFR-2 gen was detected only in three cases of cCRCC and was observed in all subjects from the control group. IGFR-2 is a protein with a single transmembrane domain, short cytoplasmatic tail, and long extracellular domain consisting of three repeats [28]. One binding IGF-2 and two different repeats binding mannose-6-phosphate-tagged proteins such as renin, prolipherin, thyreoglobulin, and the inactive form of TGF- $\beta$. Binding of IGF-2 leads to its internalisation/degradation. Loss of expression of the gene encoding this receptor was observed in breast cancer and hepatocellular carcinoma [29,30]. Loss of heterozygosity in one copy of gene and missense mutation in the second were demonstrated in both. Lack of IGFR-2 gene expression was also observed in Wilms' tumour, but in this case imprinting of the gene was the reason for this phenomenon [31]. In humans, in contrast to mice, the IGFR-2 imprinting gene probably does not exist, except in Wilms' tumours [32]. A lack of IGFR-2 increases IGF-2 availability to the cell. Expression of IGF-2 gene in ccRCC tissue and diseased kidney was been observed in all cases, but autocrine/paracrine action was not necessary. The action of systemic IGF-2 was sufficient. We can assume that the lack of expression of the IGFR-2 gene in tumour may be linked to the development of the disease. The expression in the part of the kidney free of cancer with cCRCC occurs rarely, but with higher frequency than in tumours. To explore the mechanisms of the development of ccRCC it is advisable to clarify whether the loss of expression concerns only the tumour or whether it is systemic. A very interesting group are the isolated cases (three persons) who developed ccRCC despite the fact that there was no decline of the expression of this gene. Currently they are in a follow-up to investigate whether there are diversities in the course of disease in this group.

The expression of IGFBP-3 gene is in opposition to the expression presented above. It was present in over 92\% of cCRCCS and has never been found in specimens from kidney free of cancer. Previous reports suggest that elevated serum concentration of IGFBP-3 protects against the development of cancer $[17,18,33]$. Our result does not exclude such a possibility. First of all, it concerns the tumour, and not the concentration in the blood. A few reports have presented results similar to ours. The first one, presented by Hintz et al., shows the elevated expression of $/ G$ FBP-3 gene in CCRCC tissue [34], and two others show the elevated expression of protein $[35,36]$. Several factors are known to have the ability to influence the expression of this gene. The first one is IGF-1 [37, 38]. The impact of IGF-1 on IGFBP-3 expression was investigated by Rosendahl et al. [39]. Conducting the research on mice with xerotransplanted Caki-2 tumours (cell lines of human ccRCC), they showed that administration of IGF-1 stimulates the production of IGFBP-3 by tumours. The effect was stronger in early stages of tumour growth. IGFBP-3 in our case could provide a counterbalance for the mitogenic IGF-1 action and slow down rapid tumour growth. In this manner the milder course of illness in patients with higher IGF-1 observed by Rasmuson et al. could be explained. But the expression of IGF-1 gene has been shown only in some cCRCCs. Systemic IGF-1 could promote this expression as well, but it is also present in persons without cancer, with no IGFBP3 gene expression in the kidney. We can suppose that it is not the main reason for this expression. The cause of the observed (by us) IGFBP-3 gene expression should be, however, the impact of hypoxia inducible factor (HIF)-1 $\alpha$ [40]. HIF-1 is a regulator of cellular response to hypoxia and its overexpression is observed in many tumours [41-43]. In normal oxygen conditions it is ubiquitinated. The ubiquitination requires binding to the von Hippel-Lindau (VHL) tumour suppressor protein [44]. In hypoxia or VHL gene mutation this process does not occur. Inactivation of the VHL gene due to mutation or hypermethylation is the most frequently described genetic alteration in ccRCC. According to some reports the prevalence may reach as much as 60-80\% [4547]. Induction of IGFBP-3 through HIF-1 $\alpha$-mediated mRNA transcription has been described by Natsuizaka et al. [40]. It can be assumed that expression of IGFBP-3 appears as a counteraction of the promitotic action of IGF-1. Nevertheless, it may also have the opposite effect and promote the development of cancer [48]. In light of this, the expression of IGFBP could indicate tumour malignancy. Taking into account the relationship between IGFBP-3 and the mutation of $V H L$ gene, we may suspect that the observed IGFBP-3 gene expression is an indicator of VHL gene mutation. Confirmation of this requires further research. Based on fairly unequivocal results indicating the presence of IGFBP-3 gene expression in CCRCC and the healthy part of the kidney with cancer, it could be identified as a potential diagnostic marker of ccRCC. Our study is too small to fully demonstrate the utility of IGFBP-3 gene as a biomarker, and it encourages further research. The follow-up is ongoing, and potential differences in the further course of 
the disease between patients with present or absent of IGFBP-3 gene expression would be an indication for studies on its prognostic and predictive value in cCRCC.

In conclusion, it should be said that the presented results show that there are basics for research on the use of the gene for IGFBP-3 as a diagnostic marker for CCRCC and the gene for IGFR-1 as a prognostic marker. Further research is also needed for a full explanation of the role of loss of IGFR-2 gene expression in the development of ccRCC.

\section{The authors declare no conflict of interest.}

\section{References}

1. Ljungberg B, Cowan NC, Hanbury DC, et al. EAU guidelines on renal cell carcinoma: the 2010 update. Eur Urol 2010; 14: 398-406.

2. Jemal A, Bray F, Center MM, Ferlay J, et al. Global cancer statistics. CA Cancer J Clin 2011; 61: 69-90.

3. Hung RJ, Moore L, Bofetta P, et al. Family history and the risk of kidney cancer: a multicenter case-control study in Central Europe. Cancer Epidemiol Biomarkers Prev 2007; 16: 1287-904.

4. Nawai N, Wood CG. Environmental and modifiable risk factors in renal cell carcinoma. Urol Oncol 2012; 30: 220-4.

5. Jones Jl, Clemmons DR Insulin-like growth factors and their binding proteins: biological actions Endo Rev 1995; 16: 3-34.

6. Pollak M. Insulin like growth factor physiology and cancer risk Eur J Cancer 2000; 36: 1224-8.

7. Braczkowski R, Schally AV, Plonowski A, Varga JL, Groot K, Krupa M. Inhibition of proliferation in human MNNG/HOS osteosarcoma and SK-ES-1 Ewing sarcoma cell lines in vitro and in vivo by antagonists of growth hormone-releasing hormone: effects on insulin-like growth factor II. Cancer 2002; 95: 1735-45.

8. Rowlands MA, Gunnel D, Harris R, Vatten LJ, Holly JM, Martin RM. Circulating insulin-like growth factor peptides and prostate cancer risk: a systematic review and meta-analysis. Int J Cancer 2009; 124: 2416-29.

9. Douglas JB, Silverman DT, Pollak MN. Serum IGF-I, IGF-II, IGFBP-3, and IGF-I/IGFBP-3 molar ratio and risk of pancreatic cancer in the prostate, lung, colorectal, and ovarian cancer screening trial. Cancer Epidemiol Biomarkers Prev 2010; 9: 2298-306.

10. Jenkins PJ, Mukherjee A, Shalet SM. Does growth hormone cause cancer? Clin Endocrinol (Oxford) 2006; 64: 115-21.

11. Svensson J, Tivesten $\AA$, Sjögren K, et al. Liver-derived IGF-I regulates kidney size, sodium reabsorption, and renal IGF-II expression. J Endocrinol 2007; 193: 359-66.

12. Vijayan A, Franklin SC, Delmez JA, Miller SB. Insulin-like growth factor 1 enhances renal function in a patient with chronic renal failure on peritoneal dialysis. Am J Kidney Dis 2000; 35: 150-3.

13. Chevalier RL, Goyal S, Kim A, Chang AY, Landau D, LeRoith D. Renal tubulointerstitial injury from ureteral obstruction in the neonatal rat is attenuated by IGF-1. Kidney Int 2000; 57: 882-90.

14. Fuhrman SA, Lasky LC, Limas C. Prognostic significance of morphologic parameters in renal cell carcinoma. Am J Surg Pathol 1982; 6: 655-63.

15. Ercolani L, Florence B, Denaro M, Alexander M. Isolation and complete sequence of a functional human glyceraldehyde-3-phosphate dehydrogenase gene. J Biol Chem 1988; 263: 15335-41.

16. Nakajima-lijima S, Hamada H, Reddy P, Kakunaga T. Molecular structure of the human cytoplasmic beta-actin gene: interspecies homology of sequences in the introns. Proc Natl Acad Sci U S A 1985; 82: 6133-7.

17. Schairer C, McCarty CA, Isaacs C. Circulating insulin-like growth factor (IGF)-I and IGF binding protein (IGFBP)-3 levels and postmenopausal breast cancer risk in the prostate, lung, colorectal, and ovarian cancer screening trial (PLCO) cohort. Horm Cancer 2010; 1: 100-11.

18. Vatten LJ, Holly JM, Gunnell D, Tretli S. Nested case-control study of the association of circulating levels of serum insulin-like growth factor I and insulin-like growth factor binding protein 3 with breast cancer in young women in Norway. Cancer Epidemiol Biomarkers Prev 2008; 17: 2097-100.

19. Rasmuson T, Grankvist K, Jacobsen J, Olsson T, Ljungberg B. Serum insulin-like growth factor-1 is an independent predictor of prognosis in patients with renal cell carcinoma. Acta Oncol 2004; 43: 744-8.

20. Ludovini V, Bellezza G, Pistola L, et al. High coexpression of both growth factor receptor -1(IGFR-1) and epidermal receptor (EGFR) is associated with shorter disease free survival in resected nonsmall-cell lung cancer patients Ann Oncol 2009; 20: 842-9.

21. Mountzios G, Kostopoulos I, Kotoula V, et al. Insulin-like growth factor 1 receptor (IGF1R) expression and survival in operable squamous-cell laryngeal cancer. PLoS One 2013; 8: e54048.

22. Spentzos D, Cannistra SA, Grall F, Levine DA, Pillay K, Libermann TA, Mantzoros CS. IGF axis gene expression patterns are prognostic of survival in epithelial ovarian cancer. Endocr Relat Cancer 2007; 14: 781-90.

23. Dziadziuszko R, Merrick DT, Witta SE, Mendoza AD, Szostakiewicz B, Szymanowska A. Insulin-like growth factor receptor 1 (IGF1R) gene copy number is associated with survival in operable nonsmall-cell lung cancer: A comparison between IGF1R fluorescent in situ hybridization, protein expression, and mRNA expression. J Clin Oncol 2010; 28: 2174-80.

24. Parker A, Cheville JC, Lohse C, Cerhan JR, Blute ML. Expression of insulin-like growth factor I receptor and survival in patients with clear cell renal cell carcinoma. J Urol 2003; 170: 420-4.

25. Sichani MM, Yazdi FS, Moghaddam NA, Chehrei A, Kabiri M, Naeimi A. Prognostic value of insulin-like growth factor-I receptor expression in renal cell carcinoma. Saudi J Kidney Dis Transpl 2010; 22: 69-74.

26. Yuen JS, Cockman ME, Sullivan M, et al. The VHL tumor suppressor inhibits expression of the IGF1R and its loss induces IGF1R upregulation in human clear cell renal carcinoma. Oncogene 2007; 26: 6499-508.

27. Yuen JS, Akkaya E, Wang Y. Takiguchi M, Peak S, Sullivan M, Macaulay VM. Validation of the type 1 insulin-like growth factor receptor as a therapeutic target in renal cancer. Mol Cancer Ther 2009; 8: 1448-59.

28. Orsel JG, Sincock PM, Krise JP, Pfeffer SR. Recognition of the 300kDa mannose 6-phosphate receptor cytoplasmic domain by 47kDa tail-interacting protein. Proc Natl Acad Sci U S A 2000; 97 : 9047-51.

29. Hankins GR, De Souza AT, Bentley RC, et al. M6P/IGF2 receptor: a candidate breast tumor suppressor gene. Oncogene 1996; 12: 2003-9.

30. Yamada AT, De Souza, Finkelstein S, Jirtle RL. Loss of the gene encoding M6P/IGF2R is an early event in liver carcinogenesis. Proc Natl Acad Sci U S A 1997; 94: 10351-5.

31. Xu YQ, Grundy P, Polychronakos C. Aberrant imprinting of the insulin-like growth factor II receptor gene in Wilms' tumor. Oncogene 1997; 4: 1041-6.

32. Yotova IY, Vlatkovic IM, Pauler FM, et al. Identification of the human homolog of the imprinted mouse Air non-coding RNA. Genomics 2008; 92: 464-73.

33. Rohrmann S, Grote VA, Becker S, et al. Concentrations of IGF-I and IGFBP-3 and pancreatic cancer risk in the European Prospective Investigation into Cancer and Nutrition. Br J Cancer 2012; 106: 1004-10.

34. Hintz RL, Bock S, Thorsson AV, Bovens J, Powell DR, Jakse G, Petrides PE. Expression of the insulin like growth factor-binding protein 3 (IGFBP-3) gene is increased in human renal carcinomas. J Urol 1991; 146: 1160-3.

35. Takahashi M, Papavero V, Yuhas J, Kort E, Kanayama HO, Kagawa S. et al. Altered expression of members of the IGF-axis in clear cell renal cell carcinoma. Int J Oncol 2005; 26: 923-31.

36. Chuang ST, Patton KT, Schafernak KT, Papavero V, Lin F, Baxter RC, et al. Over expression of insulin-like growth factor binding protein 3 in clear cell renal cell carcinoma. J Urol 2008; 179: 445-9.

37. Hembree JR, Harmon CS, Nevins TD, Eckert RL. Regulation of human dermal papilla cell production of insulin-like growth factor 
binding protein-3 by retinoic acid, glucocorticoids, and insulin-like growth factor-1 I Cell Physiol 1996; 167: 556-61.

38. Wraight CJ, Werther GA. Insulin-like growth factor-I and epidermal growth factor regulate insulin-like growth factor binding protein-3(IGFBP-3) in the human keratinocyte cell line HaCaT. J Invest Dermatol 1995; 105: 602-7.

39. Rosendahl AH, Holly JM, Celander M, Forsberg G. Systemic IGF-I administration stimulates the in vivo growth of early, but not advanced, renal cell carcinoma. Int J Cancer 2008; 123: 1286-91.

40. Natsuizaka M, Naganuma S, Kagawa S, et al. Hypoxia induces IGFBP3 in esophageal squamous cancer cells through HIF-1alpha-mediated mRNA transcription and continuous protein synthesis. FASEB J 2012; 26: 2620-30.

41. Wang GL, Jiang BH, Rue EA, Semenza GL Hypoxia-inducible factor 1 is a basic-helix-loop helix-PAS heterodimer regulated by cellular O2 tension. Proc Natl Acad Sci U S A 1995; 92: 5510-4.

42. Natsuizaka M, Naganuma S, Kagawa S, et al. Increased expression of hypoxia inducible factor-1alpha in rat and human prostate cancer. Cancer Res 1998; 58: 5280-4.

43. Volm M, Koomägi R. Hypoxia-inducible factor (HIF-1) and its relationship to apoptosis and proliferation in lung cancer. Anticancer Res 2000; 20: 1527-33.

44. Ohh M, Park CW, Ivan M, Hoffman MA, Kim TY, Huang LE, et al. Ubiquitination of hypoxia-inducible factor requires direct binding to the beta-domain of the von Hippel-Lindau protein. Nat Cell Biol 2000; 2: 423-7.

45. van Houwelingen KP, van Dijk BA, Hulsbergen-van de Kaa CA, Schouten LJ, Gorissen HJ, Schalken JA, et al. Prevalence of von Hippel-Lindau gene mutations in sporadic renal cell carcinoma: results from The Netherlands cohort study. BMC Cancer 2005; 5: 57.

46. Zinnamosca L, Laudisi A, Petramala L, Marinelli C, Roselli M, Vitolo D, Montesani C, Letizia C. von Hippel Lindau disease with colon adenocarcinoma, renal cell carcinoma and adrenal pheochromocytoma. Intern Med 2013; 52: 1599-603.

47. Khaliq S, Ajaz S, Firasat S, et al. Chromosome 3p loss of heterozy gosity is associated with a unique metabolic network in clear cell renal carcinoma. Mutat Res 2014; 763-764C: 45-52.

48. Butt AJ, Martin JL, Dickson KA, McDougall F, Firth SM, Baxter RC. Insulin-like growth factor binding protein-3 expression is associated with growth stimulation of T47D human breast cancer cells: the role of altered epidermal growth factor signaling. J Clin Endocrinol Metab 2004; 89: 1950-6.

\section{Address for correspondence}

\section{Ryszard Braczkowski}

Department of Public Health

School of Public Health

Silesian Medical University

Piekarska 18

41-902 Bytom, Poland

e-mail: rbracz@sum.edu.pl

Submitted: 18.10.2015

Accepted: $\quad 9.03 .2016$ 